\title{
Bridging the Digital Divide, Aiming to Become Lifelong Learners
}

\author{
Annelise Kachelhoffer and Myint Swe Khine \\ Emirates College for Advanced Education, United Arab Emirates \\ \{a.kachelhoffer, mskhine\} @ecae.ac.ae
}

\begin{abstract}
Studies in the past documented that proper use of Information and Communication Technology (ICT) can positively impact learning. It has been shown that the use of ICT can help students develop inquiry and thinking skills, increase learning opportunities, enhance learning activities, and improve learning outcomes for students. While there are bright prospects, barriers still exist in certain areas, particularly the readiness of the teachers who will adopt the technology, administrative support and technology infrastructure in schools. This study reports the patterns of computer use and computer self-efficacy among students in a postgraduate degree in education program in the UAE. The survey from 91 students were analysed and found that most students have positive attitudes and beliefs in ICT, but lacking behind the use of such technologies. The authors suggest that it is necessary to create opportunities for them to use ICT in the classroom and further develop knowledge and skills in Web 2.0 technologies.
\end{abstract}

Keywords: Computer use, Computer Self-efficacy, ICT, Web 2.0, Classroom Teaching/Practice, Empowering, Integration of ICT, Teacher Training, Digital Divide, Teacher Education, Knowledge Society, Lifelong learning.

\section{Introduction}

Knowledge creation happens any where anytime. Educators and students use a variety of innovative and necessary tools in this process. Many of these tools were not initially aimed at education and took a while to become an essential tool in the teaching learning environment. For example, the Arpanet (the forerunner of today's Internet) was introduced in 1969 [1], but it didn't become an essential tool for worldwide business, communication, and entertainment or for education for another 25-30 years. Saariluoma [1] points out that once the structure became known and accepted, it provoked a wide variety of forms of usage, products, and services. She emphasized that this example points to a modern reality: "The faster new ideas find their routes into everyday life, the broader and deeper their impact on, for instance, social development can be" (p109).

In the knowledge society technological developments and new ideas not only impact on the society but also have an influence on the fabric of the culture of a specific society. Not all of these technological developments were initially aimed at the class room, but many like the Web 2.0 technologies, Facebook, Del.cio.us, podcasting and Weblogs (blogs) etcetera became part of the information and communication technologies (ICT) teachers use to ensure a richer learning experience for their students [2]. 
There is empirical evidence that the proper use of Information and Communication Technology (ICT) can positively impact learning [3]. Major contributions of ICT have been documented in the literature and these suggest that the use of ICT can help students develop inquiry and thinking skills, increase learning opportunities, enhance learning activities, and improve learning outcomes for students. Studies in different countries show varying degrees of success in introducing ICT in schools [4][5]. While there are bright prospects, barriers still exist in certain areas, particularly the readiness of the teachers who will adopt the technology, administrative support and technology infrastructure in schools [6]. Web 2.0 is a relatively young technology and it is widely believed that it is a technology with profound potential for inducing change in the Higher Education sector, due to the catalytic effects of the Web 2.0 technologies [7]. The reality is that there are still students in the Higher Education systems in some parts of the world that are only starting to explore the value of technology on learning and teaching. This study attempts to explore the pattern of computer use and computer self- efficacy among students in the Post Graduate Diploma in Education (PGDE) at the Emirates College for Advanced Education in the United Arab Emirates.

\section{Background to the Development of the UAE and Technology in the Country}

The United Arab Emirates is a "young" nation. In 1971, six Trucial states of the Persian Gulf - Abu Dhabi, Ajman, Al Fujayrah, Sharja, Dubai, and Umm al Qaywayn merged to form the United Arab Emirates (UAE). They were joined in 1972 by Ra's al Khaymah.

The Education field developed in spurts over the last 50 years. In the early 1900's three major schools were established by pearl merchants in Dubai, Abu Dhabi and Sharja but an economic crises forced closure of these schools between $1920-1930$. In 1953 the first school that offered a comprehensive curriculum opened by the British in Sharja. In Abu Dhabi Mulla Darwish bin Karam taught children of Abu Dhabi at village religious schools during the mid 1950's. The first school built in Abu Dhabi was in 1959. During 1962 the first oil left Das Island and the fabric of the country changed. Six schools were opened in Abu Dhabi between 1964 and 1965 and at the same time thirty one schools existed outside Abu Dhabi. The British School Al Khubairat opened in Abu Dhabi in 1971 the same year the federation of United Arab Emirates was proclaimed. During the early 1970 a remarkable expansion of public education facilities was seen and education became compulsory at primary level. The country's first Higher Education institutions aimed at vocational training, the Higher Colleges of Technology, opened in 1988 and the UAE University opened in 1997 in Al Ain. During 1998 the country's first university for females only Zayed University, was established. The Abu Dhabi Education Council (ADEC) was formed in 2006 and announced ambitious school reform plans. The Emirates College for Advanced Education opened in 2007 as an initiative of ADEC as the UAE's first dedicated teacher training college.

The school reform plans announced in 2006 were very timely for the country. Mograby [8] alerted readers to the challenges the education system faced: "There is no doubt that the current education system is unable to sustain future development, 
cope with change, and realise desired national goals. The inability of the present curricula and structure to keep up with rapid technological developments, new demands of the labour market, modern communications and the information age poses a serious threat to the future of UAE society and economy." p. 302

The education reform announced by ADEC in 2006 is inter alia also looking at the provision of ICT in schools. It was reported in 2007 [9] that there was little ICT use in schools and that few schools used modern teaching and learning technology. In many cases computers are old and used for non-teaching purposes. The educational reform wants to address this digital divide [9].

The number of national teachers in the UAE currently teaching without any formal teacher education qualifications is not disclosed information, but taking the urgency in which the Federal Council and the Abu Dhabi Education Council are organizing professional development workshops for national and expat teachers, the number is estimated to be in the thousands. Students' enrolling for the Post Graduate Diploma in Education at the Emirates College for Advanced Education (ECAE) is a way for the country to address the problem.

It is accepted that some of the most innovative and promising practices in education involve technology [2] and through this research faculty at the ECAE wanted to establish the use and believes of a group of mature students who are doing a post graduate diploma to achieve a teaching qualification in the UAE. The ongoing professional development their lifelong learning skills.

\subsection{Profile of the Postgraduate Students}

The students enrolling for the PGDE profile as follows:

- Students are all nationals, meaning that the program is currently open to Emiratis only.

- The PGDE program is open to male and female students and the classes on Post Graduate level are mixed.

- Students come from a mixture of backgrounds. The majority are in-service teachers.

- Their undergraduate degrees are in the areas of Economics, English, Geography, History, Islamic Studies, Mathematics, Psychology, Science and Social Science.

- There is a number of retired military males in the group

\section{Research Objectives}

The study aims to explore how PGDE students are using computers and their attitudes towards the computers. The specific objectives of the study are to:

- Measure the extent of their experience in using computes

- Identify the familiarity of different types of software and applications and extent of their use

- Find out how the students might feel about computers, their beliefs and attitudes towards computers 


\subsection{Significance}

Many studies have been conducted to identify the barriers that can affect teacher's adoption of technology in the classroom. These barriers can be summarized as (i) infrastructure and resources, (ii) knowledge and skills, (iii) organizational culture, (iv) attitudes and beliefs, (v) nature of assessments, and (vi) subject content [10]. These barriers seem to influence the successful integration of ICT in the classroom [11]. Among them knowledge and skills and attitudes and beliefs are critically important in the readiness of the ICT use. It is clear that teachers must be confident in using ICT and they must be equipped with necessary knowledge and skills in ICT in order to effectively use the technology. The results from this study will indicate the current state of ICT use and attitudes towards computers among PGDE students.

This study will further determine whether PGDE students enter their ICT studies with the belief that ICT can contribute to learning. The information obtained from this survey will be valuable in improving the existing ICT course and planning future ICT related courses as well as other professional development programs. The ICT course for the PGDE program aims to equip the teachers with the necessary knowledge and skills in and belief and attitudes about the use of ICT in schools in accordance with strategic directives of the Ministry of Education.

\subsection{Method}

Quantitative data were collected by using the following questionnaire.

(i) Computer use questionnaire

(ii) Attitudes towards computers

The computer use questionnaire was designed to find out current use of specific software and applications, the extent of usage among PDGE students and their belief regarding the contribution ICT can make in learning. This questionnaire was developed by the researchers of this project.

The second questionnaire deals with attitudes towards computers. The questionnaire was developed by Cassidy and Eachus [12] and consisted of 30 item statements.

The students were asked to provide their responses on a six-point Likert scale to indicate the extent of agreement to each statement. The internal reliability as measured by Cronbach's alpha for the instrument was reported as 0.94 . Permission to use the instrument was obtained from the authors. The questionnaire was translated into Arabic language.

\section{Results}

In this study a total of 91 usable data sets was obtained from the total enrolment of 107 students. Among the useable data $42(46.2 \%)$ are male and $49(53.8 \%)$ are female. Students have different subject backgrounds and they are grouped into science, social science and business subjects. Out of the total number of students 42 students (46.2\%) reported that they have science subject background, 45 students $(49.5 \%)$ having humanities subject background and 4 students (4.4\%) having business subject background. 
Out of 91 students, only one student reported that he/she did not have any computer experience prior to this course. 11 students (12.1\%) reported that they have limited experience; 44 students $(48.4 \%)$ reported that they have some experience and 30 students $(33.0 \%)$ with a lot of experience. Only 5 students $(5.5 \%)$ indicated that they have extensive experience. A total of $81.4 \%$ of students indicated that they had some and a lot of computer experience. This shows that the students who come to the course had reasonable computer experience.

The data shows that 87 students $(95.6 \%)$ had internet access at home and only 4 students $(4.4 \%)$ did not have any internet at home. In terms of computer training 87 students $(95.6 \%)$ indicated that they already had some form of computer training before and only 4 students (4.4\%) indicated that they did not have prior computer training.

\subsection{Software Used by the Participants}

Participants were asked to provide to what extent they use the productivity software such as Microsoft Office suit. The extent of usage is shown in Table 1.

\subsection{Application Program Used by the Participants (Web 2.0)}

The students were also asked the extent of their usage of some of the common application programs such as blogs, wikis, podcasting, YouTube, FaceBook and TeacherTube. High numbers of students $(78 \%)$ reported that they had never used a blog before. Similarly $76.9 \%$ reported that they had never used a wiki and an even higher number of students $(83.5 \%)$ indicated that they had never used a podcast. The results on the use of other applications such as FaceBook and TeacherTube also show that high number of students never used these applications. In contrast to this trend at least $50 \%$ of students reported that they sometimes or always use YouTube. Table 2 summarises the extent of their usage.

Table 1. Software usage by students

\begin{tabular}{l|cccc}
\hline Software & Never & Seldom & Sometime & Always \\
\hline Internet Browser & 4 & 6 & 18 & 63 \\
[Explorer] & $(4.4 \%)$ & $(6.6 \%)$ & $(19.8 \%)$ & $(69.2 \%)$ \\
Email & 9 & 12 & 22 & 48 \\
[Outlook] & $(9.9 \%)$ & $(13.2 \%)$ & $(24.2 \%)$ & $(52.7 \%)$ \\
Word Processor & 4 & 8 & 16 & 62 \\
[Word] & $(4.4 \%)$ & $(8.8 \%)$ & $(17.6 \%)$ & $(68.1 \%)$ \\
Spreadsheet & 25 & 19 & 28 & 19 \\
[Excel] & $(27.5 \%)$ & $(20.9 \%)$ & $(30.8 \%)$ & $(20.9 \%)$ \\
Presentation & 5 & 9 & 24 & 52 \\
[PowerPoint] & $(5.5 \%)$ & $(9.9 \%)$ & $(26.4 \%)$ & $(57.1 \%)$ \\
Desktop Publishing & 47 & 23 & 10 & 10 \\
[Publisher] & $(51.6 \%)$ & $(25.3 \%)$ & $(11.0 \%)$ & $(11.0 \%)$ \\
\hline
\end{tabular}

\subsection{Computer Self-efficacy Score}

Computer self-efficacy score was measured by a translated Arabic version of Cassidy \& Eachus's (2002) instrument on Computer User Self-Efficacy (CUSE). The survey 
consisted of 30 items and students answered to the extent of agreement for each statement by using 6-point Likert-type scale ranging from strongly disagree (1) to strongly agree (6). The original English version survey had reliability (Cronbach's Alpha) 0.94 and the Arabic version of the survey yielded Cronbach's Alpha of 0.908. The reliability of the Arabic version seems to be comparable with the original English version. This is evidence of homogenecity within the items and an average of correlation coefficients between scale item is approaching to a maximum coefficient of 1 .

To establish the validity of the instrument a factor analysis was also conducted. Principal component analysis extraction method was used with varimax rotation. A total of 8 components were extracted from the data. Out of 30 items 24 items loaded on one scale with the factor loading ranging from 0.437 to 0.729 . Keiser-Meyer-Olkin measure of sampling adequacy yielded a high value (.0800) and this indicates that the factor analysis may be useful and confirmed that the instrument has a single construct with high validity.

\subsection{Gender Differences}

The mean computer self-efficacy score for male students was 4.731 with the standard deviation of 0.620 and the score for female students was 4.538 with the standard deviation of 0.730 . Although the self-efficacy score was higher in male students, the difference is statistically not significant. This means that female students are not far behind in computer efficacy. According to researchers having a high degree of computer self-efficacy has been identified as a significant factor in improving attitudes towards the use of computers.

Table 2. Application programs usage by students

\begin{tabular}{l|cccc}
\hline Programs & Never & Seldom & Sometime & Always \\
\hline Blog & 71 & 10 & 8 & 2 \\
& $(78.0 \%)$ & $(11.0 \%)$ & $(8.8 \%)$ & $(2.2 \%)$ \\
Wiki & 70 & 5 & 8 & 8 \\
& $(76.9 \%)$ & $(5.5 \%)$ & $(8.8 \%)$ & $(8.8 \%)$ \\
Podcast & 76 & 5 & 6 & 2 \\
& $(83.5 \%)$ & $(5.5 \%)$ & $(6.6 \%)$ & $(2.2 \%)$ \\
YouTube & 29 & 16 & 17 & 29 \\
& $(31.9 \%)$ & $(17.6 \%)$ & $(18.7 \%)$ & $(31.9 \%)$ \\
FaceBook & 69 & 8 & 9 & 5 \\
TeacherTube & $(75.8 \%)$ & $(8.8 \%)$ & $(9.9 \%)$ & $(5.5 \%)$ \\
& 68 & 12 & 8 & 3 \\
& $(74.7 \%)$ & $(13.2 \%)$ & $(8.8 \%)$ & $(3.3 \%)$ \\
\hline
\end{tabular}

\subsection{Subject Background Differences}

The results show that students with a science subject background had a computer selfefficacy score of 4.757 with a standard deviation of 0.654 , and those with a humanities background had a score of 4.563 with a standard deviation of 0.696 . This shows that self-efficacy of science students are higher than their counterparts with humanities subject background. The difference is statistically significant at $\mathrm{p}>.05$ level. This 
may be due to the fact that science students tend to use more computers and there are many applications and examples available for science subjects.

\subsection{Interscale Correlations with Background Variables}

The Table 3 illustrates the correlation between computer self-efficacy score and background variables. As described above gender has no effect on the computer self-efficacy score. But subject background has a significant effect on the computer self-efficacy score and correlation is significant at $\mathrm{p}>0,05$ level. Students with a science subject background had a higher computer self-efficacy score than those with humanities subject background.

Again the students' prior computer experience has some effect on computer selfefficacy score. Those who had more experience in using computers tend to score higher on efficacy.

Whether or not the students had internet access at home does not seem to have any effect on computer self-efficacy, but there is a significant correlation between computer training and computer experience. Students who had training tend to use more computers and gain more experience. The results also show that those who had computer training have internet at home.

Table 3. Interascale correlations

\begin{tabular}{|c|c|c|c|c|c|c|}
\hline & Gender & $\begin{array}{l}\text { Subject } \\
\text { background }\end{array}$ & $\begin{array}{l}\text { Computer } \\
\text { experience }\end{array}$ & $\begin{array}{l}\text { Internet } \\
\text { at home }\end{array}$ & $\begin{array}{l}\text { Computer } \\
\text { training }\end{array}$ & $\begin{array}{l}\text { Computer } \\
\text { self-efficacy } \\
\text { score }\end{array}$ \\
\hline Gender & & $\begin{array}{l}-0.097 \\
\end{array}$ & 0.152 & -0.124 & -0.124 & -0.141 \\
\hline $\begin{array}{l}\text { Subject } \\
\text { background }\end{array}$ & -0.097 & & -0.162 & -0.124 & -0.124 & $-0.228^{*}$ \\
\hline $\begin{array}{l}\text { Computer } \\
\text { experience }\end{array}$ & 0.152 & -0.162 & & -0.013 & $-0.216^{*}$ & $0.500 * *$ \\
\hline $\begin{array}{l}\text { Internet at } \\
\text { home }\end{array}$ & -0.124 & -0.124 & -0.013 & & $0.477 * *$ & 0.009 \\
\hline $\begin{array}{l}\text { Computer } \\
\text { training }\end{array}$ & -0.124 & -0.124 & $-0.216^{*}$ & $0.477 * *$ & & -0.106 \\
\hline $\begin{array}{l}\text { Computer } \\
\text { self-efficacy } \\
\text { score }\end{array}$ & -0.124 & $-0.228 *$ & $0.500 * *$ & -0.009 & -0.106 & \\
\hline
\end{tabular}

\subsection{Students' Belief in the Contribution of ICT}

Students' belief in the contribution of ICT in teaching and learning was measured by 6 item Likert type scale. Students responded on a six-point scale from 1 (strongly disagree) to 6 (strongly agree). The sample questions are:

ICT can help students develop in critical thinking

ICT can help students engage in learning activities

ICT can help students increase their learning opportunities

The reliability of this 6-item questionnaire yielded Cronbach's Alpha of 0.90 . Gender differences were computed to see whether there is any significant difference 
in beliefs among male and female students. The mean score of male students was 29.26 and females score 28.75 . However this difference is statistically not significant. Similarly no statistical differences were detected between subject background, experience, internet at home, and computer training. It was found that there is a significant correlation between the computer self-efficacy score and students' belief in the contribution of ICT at $\mathrm{p}>0.05$ level.

\subsection{Implication Regarding Software and Application Use}

The results of the questions asking about the use of software like Microsoft packages, (Table 1) and application software, like Web 2.0 technologies (Table 2) urged the faculty to develop a course for these students that -

- involves students developing and using their own Blogs as well as participating in the course blog,

- involves students to sign up and use wikis and

- introduces students to benefits and limitations of Facebook and TeacherTube in teaching.

The uptake of students using blogs is encouraging. Not only are they actively involved in the course blog, but they are using blogs now in their own teaching back in schools. Further research into this is currently underway.

\section{Conclusion}

The study shows that students are only using basic productivity tools such as wordprocessing and presentation software. The vast majority of the students are not using other productivity tools such as Excel and desktop publishing software. In terms of Web 2.0 technologies only small numbers of teachers $(<10 \%)$ are found to be using Blogs, Wikis and Podcasts. Although YouTube seems to be popular among the students, it may only be for personal use rather than as an education application. The majority of them do not have experience in using a dedicated site like TeacherTube.

While they have positive attitudes and beliefs in the contribution of ICT, they are behind in actual usage of other productivity tools and technologies. This could be due to a lack of awareness, knowledge and skill in such technologies. In order to keep up with the technology, they need to be exposed to educational application of those technologies. The course on effective use of ICT has the aim to develop students' understanding, skills and curiosity for the use of ICT to encourage learning.

It is hoped that introducing ICT as productivity tool, tutoring tool and collaboration and communication tools will provide the students with knowledge, understanding and familiarity with the range of information and communication technologies. As reported in this paper (Implication regarding software and application use) this is already happening with in-service students taking this course. It is expected that the Abu Dhabi Education Council and Ministry of Education will continue develop and provide infrastructure and opportunity for the teachers to use such technologies in their teaching. 


\section{Acknowledgement}

The authors wish to thank Cassidy and Eachus for the permission to use the Computer use self-efficacy instrument. The authors also want to thank Christine Thorne for drawing on her knowledge regarding the development of the UAE.

\section{References}

1. Saariluoma, P.: Open Access Publishing as an Incorporator of Research and Innovation Cycle. Human Technology - An Interdisciplinary Journal on Humans in ICT environments. Special issue on ICT in education 1, 109-110 (2005)

2. Roblyer, M.D.: Integrating Educational Technology into Teaching. Prentice-Hall, New Jersey (2006)

3. Josassen, D.: Computers as Mindtools for Schools: Engaging Critical Thinking. PrenticeHall, Columbus (2000)

4. Tearle, P.: A theoretical and instrumental framework for implementing change in ICT in education. Cambridge Journal of Education 34, 331-351 (2004)

5. BECTA (British Educational Communications and Technology Agency): Improving Learning and Teaching with ICT. BECTA, Coventry (2006)

6. Markauskaite, L.: Exploring the structure of trainee teachers' ICT literacy: the main components of and relationships between, general cognitive and technical capabilities. Educational Technology Research and Development 55, 547-572 (2007)

7. Franklin, T., Van Harmelen:

http://www.jisc.ac.uk/media/documents/programmes / digitalrepositories/web2-content-learning-and-teaching.pdf

8. Mograby, A.: Human Development in the United Arab Emirates: Indicators and Challenges ECSSR, Education and the Arab World, 282 (1999)

9. Macpherson, R., Kachelhoffer, P., Nemr, M.: The Radical Modernization of School and Education System Leadership in the United Arab Emirates: Towards Indigenized and Educative Leadership. International Studies in Educational Administration. Journal of the Commonwealth Council for Educational Administration and Management 35, 60-77 (2007)

10. Leask, M., Meadows, J. (eds.): Teaching and Learning with ICT in the Primary Schools. Routledge Falmer, London (2000)

11. Cuban, L.: Oversold and underused: Computers in the classroom. Harvard University Press, Boston (2003)

12. Cassidy, S., Eachus, P.: Developing the computer user self-efficacy (CUSE) scale: Investigating the relationship between computer self-efficacy, gender and experience with computers. Journal of Educational Computing Research 26, 169-189 (2002) 